\title{
SOME BIOCHEMICAL BLOOD PARAMETERS OF GATACKO BREED COWS IN EARLY LACTATION
}

\author{
Đorđe Savić, Stoja Jotanović, Marinko Vekić \\ University of Banjaluka, Faculty of Agriculture, \\ Bulevar vojvode Petra Bojovića la, 78000, Banjaluka, Bosnia and Herzegovina \\ djordjevet@yahoo.com
}

\begin{abstract}
This paper presents values of biochemical blood parameters of seven Gatacko breed cows in early lactation, and their interpretation according to the lactational stage and nutrition. Mean concentrations of albumines, globulines and total proteins $(40.14 \pm 4.88,52.57 \pm 7.76$ and $92.57 \pm 10.50 \mathrm{~g} / \mathrm{l}$, respectively) indicated dehidration and hemoconcentration. Activities of AST and ALT (131.29 \pm 28.52 and $73.14 \pm 13.50 \mathrm{U} / \mathrm{l}$, respectively) and hyperbilirubinemy $(30.14 \pm 6.96 \mu \mathrm{mol} / \mathrm{l})$ indicated liver damage by presence of liver fluke larvae, potentiated with influence of lactational stage and low nutritive status. Mean values of cholesterole, urea and calcium concentrations (4.32 $\pm 1.75,6.36 \pm 1.78$, and $2.42 \pm 0.18 \mathrm{mmol} / \mathrm{l}$, respectively) were in the physiological range, but finding of hyperphosphatemia $(2.37 \pm 0.47 \mathrm{mmol} / \mathrm{l})$ and altered calcium-phosphorus ratio, indicated mineral disbalance in ration. These findings were in accordance with data from our previous study, conducted on the same cattle breed.
\end{abstract}

Key words: Gatacko breed cows; blood biochemical parameters; early lactation

\section{НЕКОИ БИОХЕМИСКИ ПАРАМЕТРИ НА КРВТА КАЈ КРАВИ ВО РАНА ЛАКТАЦИЈА ОД РАСАТА ГАТАЧКО ГОВЕДО}

\begin{abstract}
Во трудот се презентирани вредности на некои биохемиски параметри на крвта кај седум крави од расата гатачко говедо, во рана лактација, и нивно толкување според лактациската фаза и исхрана. Концентрациите на албумини, глобулини и вкупни протеини $(40,14 \pm 4,88,52,57 \pm 7,76$ и 92,57 $\pm 10,50 \mathrm{~g} / 1$, соодветно) укажува на дехидратација и хемоконцентрација. Активностите на AST и ALT $(131,29 \pm 28,52$ и 73,14 $\pm 13,50$ $\mathrm{U} / 1$, последователно) и хипербилирубинемијата $(30,14 \pm 6,96 \mu \mathrm{mol} / \mathrm{l})$ покажаа оштетување на црниот дроб, со присуство на голем црнодробен метил, потенцирано со влијанието на лактациската фаза и нискиот нутритивен статус. Средните вредности на холестерол, уреа и концентрацијата на калциум $(4,32 \pm 1,75,6,36 \pm 1,78$ и $2,42 \pm 0,18 \mathrm{mmol} / 1$, последователно) беа во физиолошки опсег, но утврдувањето на хиперфосфатемија $(2,37 \pm$ $0,47 \mathrm{mmol} / \mathrm{l})$ и измени во соодносот калциум-фосфор, посочува на дисбаланс во односот на минерали. Овие наоди се во согласност со податоците од нашата претходна студија, спроведена на истата раса крави.
\end{abstract}

Клучни зборови: гатачка раса крави; биохемиски параметри на крв; рана лактација

\section{INTRODUCTION}

The transitional period and early lactation are the most critical periods in the productive cycle of dairy cows. The occurrence of health disorders in this period is particularly common in breeds selected for high milk yield, because their body is suffering from great metabolic burden due to inability to comply milk production with intake of nutrients through diet. Therefore, special attention should be paid to the nutrition of cows and monitor- ing their health during the period of increasing milk production. Many researchers suggest that metabolic disorders (ketosis, puerperal paresis, fatty liver, sub-acute ruminal acidosis) are dominant in the structure of health disorders of dairy cows, which reduces milk production and hampering the establishment of postpartum reproductive activity. Selection for high milk production has led to significant shortening of the productive life of cows and reducing the total lifetime production of milk 
per cow, which increases the culling rate and threatens the survival of farm (Drackley, 1999).

All the above mentioned indicates the need for detecting breeds and individuals which possess desirable characteristics of minor needs in nutrition, greater resistance to metabolic diseases, regular reproductive activity and longer productive life. Particularly interesting are indigenous cattle breeds and breeds of regional importance, such as Busha, Gatacko, Podolsko, Posavsko and Istrian cattle. A limited number of animals and mostly extensive pasture and exploitation, as well as many years of forcing highly productive breeds, conditioned that the information on these breeds is very scarce in the literature.

One of these breeds is Gatacko cattle, grown in the wider region of Herzegovina. This breed is a regional Busha strain, improved by genes of gray and brown Alpine cattle (former Oberintaal and Viptaal breed) and grown in more favorable conditions of nutrition and care, which gave slightly larger animals, with combined productive characteristics, good health and regular fertility. More information about the origin of this breed and its characteristics is available in the papers of Mićunović (1947) and Ilančić (1952).

Although some data can be found in the literature on the exterior and morphometric characteristics of this breed (Važić et al., 2007, Rogić et al., 2011), there is an evident lack of literature data in terms of their productive and reproductive capabilities and parameters of the metabolic status of the various stages of the productive and reproductive cycle. To our knowledge, available data about that are only the research results of Savić et al. (2011) in the Ministry of Agriculture, Forestry and Water Management of the Republic of Srpska project titled "Investigation of morphometric, productive and reproductive performance and genetic profiles of Gatacko cattle in the Herzegovina region".

The aim of the present study is to show blood biochemical parameters of Gatacko breed cows during early lactation, and, taking into account the ration composition and milk yield, to assess their metabolic status.

\section{MATERIAL AND METHODS}

The study was conducted on a total of $7 \mathrm{Ga}-$ tacko breed cows from eastern Herzegovina, during the winter feeding period. All examined cows were in the early stage of lactation (16-62 days, an average of $45.71 \pm 19.13$ days) and gave an average of
$16.57 \pm 1.99$ liters of milk a day (14-20). The average body weight of the examined cows, determined by a measuring tape, was $441.43 \pm 36.71 \mathrm{~kg}$ (400$500)$, and the average age of $7.86 \pm 3.48$ years (211). All cows were kept in indoor stalls, in terms of nutrition and care characteristic for a given area and period of the year. The ration consisted of dry roughages (hay at the rate of about $12 \mathrm{~kg}$ per cow per day), without added concentrates. According to the data obtained from the owner, the examined animals were given salt twice weekly (one handful of salt per cow), and during the first week after calving, bran mixed in warm water. The watering was performed once per day, with 30-40 liters of water per head. Animals showed no signs of health disorders, and, according to data obtained from the owner, estrus cycles and fertility were regular.

Blood samples were taken by puncture of $\mathrm{v}$. coccigea in sterile vacutainers without any anticoagulant. After spontaneous clotting at room temperature and separation of blood clot, blood serum was separated by centrifugation, and then deep frozen until analysis. The values of blood biochemical parameters (concentrations of total protein, albumin, globulin, total bilirubin, cholesterol, urea, calcium, and phosphorus, activity of AST and ALT) were determined on the biochemical analyzer VetTest Chemistry Analyzer, IDEXX Laboratories, UK.

Simultaneously with taking blood samples, hay samples were taken for analysis of chemical composition. Nutrient analysis was performed by the standard Weende procedure. The feed samples were analyzed for the content of dry matter, ash, crude protein, cellulose, calcium and phosphorus, and then calculation of energy and nutritional value of the ration was made.

The results were statistically analyzed by descriptive statistic methods and presented in tables.

\section{RESULTS AND DISCUSSION}

A particular problem in the detection of health disorders of dairy cows is the fact that they are predominantly subclinical. Insight into the nutritional and metabolic status on the herd level can be acquired on the basis of analysis of the composition and consumption of ration, milk production, concentration and the ratios of organic milk constituents, and on the basis of blood biochemical analysis (Savić et al., 2010). In making valid diagnosis of health disorders of etio-pathogenesis the results of the above mentioned analysis, as well as housing 
conditions and care, should be taken into account (van Saun, 2000).

Analysis of the ration (data not shown) revealed that the composition and quantity of consumed feed were below the lower limit of the needs for dairy cows of the given body weight and milk production recommended by Grubić and Adamović (1998). We found energy deficit of approximately $50 \%$ and deficit of crude protein of about $40 \%$. It should be noted that the ration was entirely based on the use of dry forage, from which the exploitation of nutrients was further limited by high content of cellulose and lignin. Radović et al. (2011), in a survey conducted in Simmental cows, found that the deficit of dry matter intake with insufficient supply of energy and protein affects the health and milk production adversely, which can be applied to cows included in this study.

Because of the lack of reference values of biochemical parameters of blood for this breed of cattle in existing literature, the results were compared with the reference values for cattle given by Ivanov et al. (2005), Kaneko et al. (2008), and results of our previous earlier study (Savić et al., 2011).

The results of determination of biochemical parameters of the examined animals blood are given in Table 1.

Table 1

Values of biochemical parameters of blood of examined cows $(n=7)$

\begin{tabular}{lcccc}
\hline \hline \multirow{2}{*}{ Parameter } & Mean $\pm \mathrm{SD}$ & \multicolumn{3}{c}{ Refferences } \\
\cline { 3 - 5 } & & Ivanov et al. (2005) & Kaneko et al. (2008) & Savić et al. (2011) \\
\hline Total protein (g/l) & $92.57 \pm 10.50$ & $60.00-80.00$ & $67.40-74.60$ & $94.36 \pm 9.86$ \\
Albumines (g/l) & $40.14 \pm 4.88$ & $30.00-40.00$ & $30.30-35.50$ & $40.55 \pm 4.50$ \\
Globulines (g/l) & $52.57 \pm 7.76$ & - & $30.00-34.80$ & $53.91 \pm 7.87$ \\
A:G ratio & $0.77 \pm 0.13$ & - & - & $0.76 \pm 0.12$ \\
AST (U/l) & $131.29 \pm 28.52$ & - & $78-132$ & $129.45 \pm 23.39$ \\
ALT (U/l) & $73.14 \pm 13.50$ & - & $11-40$ & $71.27 \pm 15.39$ \\
Total bilirubine ( $\mu \mathrm{mmol} / \mathrm{l})$ & $30.14 \pm 6.96$ & $0.85-6.80$ & $0.17-8.55$ & $25.55 \pm 8.70$ \\
Cholesterole $(\mathrm{mmol} / \mathrm{l})$ & $4.32 \pm 1.75$ & $1.29-6.32$ & $2.07-3.11$ & $4.16 \pm 1.40$ \\
Urea (mmol/l) & $6.36 \pm 1.78$ & $1.66-6.66$ & $7.14-10.7$ & $6.06 \pm 1.79$ \\
Calcium $(\mathrm{mmol} / \mathrm{l})$ & $2.42 \pm 0.18$ & $2.00-3.00$ & $2.43-3.10$ & $2.50 \pm 0.22$ \\
Phosphorus $(\mathrm{mmol} / \mathrm{l})$ & $2.37 \pm 0.47$ & $1.60-2.30$ & $1.81-2.10$ & $2.38 \pm 0.39$ \\
Ca:P ratio & $1.06 \pm 0.26$ & - & - & $1.08 \pm 0.20$ \\
\hline \hline
\end{tabular}

The concentration of total protein and protein fractions is an indicator of the functional state of the liver, as well as the individual health status. The average concentration of total protein was above the upper limit of the reference interval given by Ivanov et al. (2005) and Kaneko et al. (2008), while in comparison with the results of our earlier studies (Savić et al., 2011) slightly lower values were found. The concentration of total protein was higher in comparison with the results given by Radović et al. (2011), who found the total protein concentration of $81.70 \pm 3.20 \mathrm{~g} / 1$ in early lactation cows. The average concentrations of albumins and globulins were slightly lower $(40.14 \pm$ 4.88 vs. $40.55 \pm 4.50$ and $52.57 \pm 7.76$ vs. $53.91 \pm$
$7.87 \mathrm{~g} / \mathrm{l}$, respectively), while the ratio of albumin and globulin was slightly higher than the values found in our previous study $(0.77 \pm 0.13$ vs. $0.76 \pm 0.12$ ).

The analysis of individual results showed that the concentration of the total protein was below the limit of $80 \mathrm{~g} / 1$ in only one cow, whereas the concentrations of albumins and globulins were elevated in all examined cows. Hyperproteinemia, as well as high concentrations of protein fractions can be attributed to the unfavorable balance of water, or hemoconcentration (Stojević et al., 2008). In support of dehydration as an origin of hyperproteinemia are the data on daily water consumption, 
which is lower than the recommended 55 liters (Grubić and Adamović, 1998), and the fact that cows were fed only hay. Elevated concentrations of globulins and their dominance in the blood serum indicate the presence of inflammatory processes (Ivanov et al., 2005), probably as a consequence of chronic distomatosis, which was confirmed by the data obtained from the owner about cows dehelminthization. However, the stable concentrations of albumin and albumin/globulin ratio indicate preserved functional liver capacity, and significant adaptive capacity to adverse conditions of nutrition and care.

The average activity of AST and ALT was slightly higher than in our previous study $(131.29 \pm$ 28.52 vs. $129.45 \pm 23.39$, and $73.14 \pm 13.50$ vs. $71.27 \pm 15.39 \mathrm{IU} / 1$, respectively). The activity of AST remained within the reference interval according to Kaneko et al. (2008), while the ALT activity was almost twice higher than the upper limit of the reference interval (11-40 IU/1). The values of the average activity of both enzymes were significantly higher compared to the results given by Stojević et al. (2005), who found values of $57.79 \pm 16.49 \mathrm{U} / 1$ (AST), and $8.91 \pm 2.23 \mathrm{U} / 1$ (ALT) in early lactation cows. Analysis of individual results showed that the activity of ALT was elevated in all examined cows. The activity of AST was within the reference interval in three cows, while in the other four it was elevated.

These findings, in addition to the aforementioned hypothesis of damaging the liver by the presence of liver fluke larvae, can also be correlated with the stage of lactation. It is well known that during early lactation the liver suffers enormous metabolic load (Šamanc, 2010). In support to the hypothesis about the effect of lactation stage on the degree of liver damage, is the value of average total bilirubin concentration, which is higher compared to our previous results $(30.14 \pm 6.96$ vs. $25.55 \pm 8.70 \mu \mathrm{mol} / \mathrm{l})$. A similar trend was found by Radović et al. (2011), who found that the total bilirubin concentration was highest in cows in early lactation. In interpretation of the etiology of increased concentrations of total bilirubin, as in the previous study, the characteristics of the area (over $1000 \mathrm{~m}$ above the sea level), and the existence of relative hypoxia should be taken into account, which results in increased hemoglobin concentration and stimulation of erythropoiesis (Sjastaadt et al., 2003). Therefore, the elevated concentration of total bilirubin can be partly the attributed to adaptation to environmental conditions. In support of this assertion is the fact that the hyperbilirubinemia was found in all cows, as in our previous study.

The average concentration of cholesterol $(4.32 \pm 1.75 \mathrm{mmol} / \mathrm{l})$ was within the interval given by Ivanov et al. (2005), while in comparison to the value specified by Kaneko et al. (2008) and the results of our previous study it was higher. Elevated concentrations of cholesterol, especially in cows in early lactation, indicate hepatocyte damage, so they cannot receive and process blood cholesterol which comes from the adipose tissue as a result of lipomobilization. Analysis of individual results showed that the cholesterol level was above the upper reference limit by Ivanov et al. (2005) only in one animal, which can be correlated with its age (ten years). In all other animals values were within the reference interval. In comparison with the results of our previous study $(4.16 \pm 1.40$ $\mathrm{mmol} / \mathrm{l}$ ), we found slightly higher concentrations of cholesterol, probably as a consequence of the lactation stage.

The concentration of urea is an indicator of supply of energy and protein by ration, as well as their utilization (Stojević et al., 2002, Horvat et al., 2007). Depending on the selected reference value, the average concentration of urea found in our study $(6.36 \pm 1.78 \mathrm{mmol} / \mathrm{l})$ can be interpreted as physiological (according to Ivanov et al., 2005) or decreased (Kaneko et al., 2008). A similar situation is with the values for individual animals, which clearly indicates the importance of the choice of reference values for each parameter in these studies. The found value is higher compared to our previous one and the results found by Radović et al. (2011) $(6.06 \pm 1.79 \mathrm{mmol} / 1$ and $5.6 \pm 0.67 \mathrm{mmol} / 1$, respectively). For these reasons, these findings should be interpreted with the results of a ration analysis, where energy and protein deficit was found. The strong energy deficit and high cellulose content (35.6\%) in the diet prevent the breakdown of protein from the ration and synthesis of microbial protein in the rumen, leading to the exhaustion of the organism and reduction of milk production. A high percentage of cellulose in the hay samples, as in our previous study, suggests inadequate time of mowing and storing of hay, which is characteristic for a given area, because the cows are mostly put to pastures during the year, so small areas remain for mowing hay.

The concentration of calcium and phosphorus in the blood serum is considered as a primary indicator of mineral status of cows (Stojević et al., 2002, Ivanov et al., 2005). Similar to our previous study, calcemia was within physiological limits, 
while phosphatemia was above the upper physiological limit $(2.37 \pm 0.47 \mathrm{mmol} / \mathrm{l})$. Both calcemia and phosphatemia were lower in comparison with our previous results $(2.42 \pm 0.18$ vs. $2.50 \pm 0.22$ and $2.37 \pm 0.47$ vs. $2.38 \pm 0.39 \mathrm{mmol} / \mathrm{l}$, respectively), but higher in comparison with the results given by Radović et al. (2011). The average value of the calcium/phosphorus ratio $(1.06 \pm 0.26: 1)$ indicates a negative relationship between calcium and phosphorus in the diet, and increased excretion of calcium through milk. This relationship is more narrowed in comparison with the results of our previous study (1.08 $\pm 0.20: 1)$, probably as a result of the stage of lactation.

\section{CONCLUSION}

The results of this study represent a contribution to the data about values of biochemical parameters of metabolism in Gatacko breed cows, as an indigenous cattle breed of regional significance and potentially interesting genetic resource. Based on the analysis of the composition and quantity of food consumed, housing conditions and care, as well as the values of blood biochemical parameters during the early lactation period, we found hemoconcentration due to unfavorable water balance, liver damage as a result of parasitary infestation and inadequate supply of nutrients through diet. At the same time, preserved synthetic function and functional liver capacity, with data of daily and life milk production, regular reproduction and length of productive life, indicate significant resistance of this cattle breed to adverse conditions of nutrition, housing and care .

These results should be confirmed on a larger number of individuals, which would open up possibilities for improving the productive and reproductive traits of this breed by better feeding and care and selection of the best individuals from the existing population, and also its use as a resource for the melioration of high yielding cattle breeds in terms of resistance to metabolic and other health disorders.

\section{REFERENCES}

[1] Drackley, J. K. (1999): Biology of Dairy Cows During the Transition Period: the Final Frontier?, J. Dairy Sci. 82, 2259-2273.
[2] Grubić, G. A., Adamović, M. (1998): Ishrana visoko produktivnih krava. Poljoprivredni fakultet Beograd-Zemun.

[3] Horvat, J., Katić, V., Šamanc, H., Kirovski, D. (2007): Zdravstveni poremećaji visokomlečnih krava u ranoj fazi laktacije i njihov uticaj na higijensku ispravnost sirovog mleka, VSI Subotica.

[4] Ilančić, D. (1952): Gatačko govedo - vrelo za oplemenjivanje naše buše. Stočarstvo, 4, 145-156.

[5] Ivanov, I., Šamanc, H., Vujanac, I., Dimitrijević, B. (2005): Metabolički profil krava. Zbornik radova 4. Simpozijuma "Ishrana, reprodukcija i zaštita zdravlja goveda - Etiopatogeneza i dijagnostika poremećaja metabolizma i reprodukcije goveda", Subotica, 27. septembar-01. oktobar 2005, 241-247.

[6] Kaneko, J. J., Harvey, J. W., Bruss, M. L. (2008): Veterinary Clinical Biochemistry of Domestic Animals. London, Academic press, Sixth Edition.

[7] Mićunović, M. (1947): Gatačko goveče, Stočarstvo, 3, 119-122.

[8] Radović, B., Jotanović, S., Savić, Đ., Nitovski, A. (2011): Biohemijski parametri krvi krava simentalske rase u različitim fazama reproduktivnog ciklusa, Veterinarski glasnik, 65, 3-4, 191-201.

[9] Rogić, B., Važić, B., Jovanović, S., Stamenković-Radak, M., Savić, M., Ravić, I. (2011): Ispitivanja varijabilnosti morfometrijskih karakteristika buše i gatačkog goveda u cilju očuvanja autohtonog genoma, Veterinarski glasnik, $65,1-2,61-69$.

[10] Šamanc, H. (2010): Bolesti organa za varenje goveda, Naučna knjiga, Beograd.

[11] Savić Đ., Jotanović S., Drinić M., Vekić M. (2011): Neki biohemijski parametri krvi krava gatačke rase iz regije Gacko, Savremena poljoprivreda, vol. 60, 1-2, 31-37.

[12] Savić Đ., Matarugić D., Delić N., Kasagić D., Stojanović M. (2010): Određivanje organskih sastojaka mleka kao metoda ocene energetskog statusa mlečnih krava, Veterinarski glasnik, 64, 1-2, 21-32.

[13] Sjaastad, O., Hove, O., Sand, K. (2003): Physiology of Domestic Animals, Scandinavian Vetarinary Press, Oslo.

[14] Stojević, Z., Filipović, N., Božić, P., Tuček, J., Daud, J. (2008): The metabolic profile of Simmental service bulls, Veterinarski arhiv, 78, 2, 123-129.

[15] Stojević, Z., Milinković-Tur, S., Zdelar-Tuk, M., Piršljin, J., Galić, G., Bačić, I. (2002): Blood minerals and metabolites as an indices of metabolic disturbances in dairy cattle, Praxis Veterinaria, 50, 261-264.

[16] Stojević, Z., Piršljin, J., Milinković-Tur, S., Zdelar-Tuk, M., Beer Ljubić, B. (2005): Activities of AST, ALT and GGT in clinically healthy dairy cows during lactation and in dry period, Veterinarski arhiv, 75, 1, 67-73.

[17] Van Saun, R. (2000): Blood Profiles as Indicators of Nutritional Status, Advances in Dairy Technology, 12, 401410.

[18] Važić, B., Drinić, M., Kasagić, D., Erbez, M., Kralj, A., Rogić, B. (2007): Morfometrijske karakteristike gatačkog goveda. Agroznanje, 8 (3), 53-60. 